\title{
Visual Impact Assessment: Where Have We Come from and Where Are We Going?*
}

\author{
Richard C. Smardon \\ Department of Environmental Studies, SUNY College of Environmental Science and Forestry, Syracuse, USA \\ Email:rsmardon@esf.edu
}

How to cite this paper: Smardon, R.C. (2016) Visual Impact Assessment: Where Have We Come from and Where Are We Going? Journal of Environmental Protection, 7, 1333-1341.

http://dx.doi.org/10.4236/jep.2016.710116

Received: May 23, 2016

Accepted: September 25, 2016

Published: September 28, 2016

Copyright $\odot 2016$ by author and Scientific Research Publishing Inc. This work is licensed under the Creative Commons Attribution International License (CC BY 4.0).

http://creativecommons.org/licenses/by/4.0/

\begin{abstract}
This paper is a historical overview of the development of visual impact assessment (VIA) methodology as implemented by US Federal agencies from the 1960s until the current time. VIA methods are to be used as part of environmental impact assessment for projects which could have significant impact on landscape aesthetics. Also included are methodological challenges with current large-scale renewable energy development in the US and Europe.
\end{abstract}

\section{Keywords}

Visual Impact Assessment, Methodology History, Federal Agencies, Challenges

\section{Introduction}

In the 1960's and 1970's there were many funded and/or permitted federal projects that were at a standstill because of lack of public involvement and/or incorporation of environmental and social values [1] \& [2]. With the passage of the National Environmental Policy Act (NEPA) in 1970 [3] there now had to be incorporation of environmental values into the decision making process. Aesthetics is one of these values so the 1970's and 1980's saw an evolution and development of visual landscape management systems by a number of Federal agencies [1] [2] \& [4]. This paper will describe this evolution of visual/landscape/scenic management systems from the 1970's to current time with particular emphasis on development of "defensible" visual impact assessment (VIA) methods.

The US Forest Service [5], USDI Bureau of Land Management [6] and the Soil Conservation Service [7], which became the Natural Resources Conservation Service

${ }^{*}$ An earlier version of this paper was presented at the $39^{\text {th }}$ Annual National Association of Environmental Professionals Conference, Changing Tides and Shifting Sands April 7-10, 2014, St. Petersburg, Florida. 
(NRCS), were the early leaders among US Federal Agencies.

The US Forest service faced blockage of a number of timber management plans in 1970 's due to lack of public input and consideration of environmental values such as wildlife habitat and aesthetics within the review process, particularly in the Pacific Northwest [1] \& [2]. Bacon, Orr and other landscape architects developed the early Visual Management System with ideas from several US Forest Service regions [2]. In 1972 the US Forest Service in Washington DC backed the development of this same system and decided to implement this system [8] \& [9] within two forest service regions in the Pacific Northwest. Further input and review was received from R. Burton Litton, Jr. who produced one of the first Forest Service method papers on visual control points in 1973 [10]. The Forest Service Visual Management System (VMS) was put in US Forest Service regulations in 1976 [11] and was gradually implemented throughout many Federal Forests as part of timber management and land use management planning from 1975 to 1976 and thereafter [2] \& [5]. In 1995 the US Forest Service updated this system to a Scenic Management System developed by Lee Anderson [12]. Both systems include landscape classification, visibility of activities to sensitive users, and ability of the landscape to absorb visual impact. A series of handbooks were developed after 1976 to address the potential impacts of various activities such as timber management, utility lines and recreational development.

The USDI Bureau of Land Management (BLM) has purview over grazing permits on Federal lands, some forestry activities, oil and gas development, and mining activity (until recently). In the mid 1970's Robert Leopold, head landscape architect for BLM, with the input from some that worked on the Forest Service's VMS developed their own VMS. This system included landscape classification of scenic attributes, visibility distance zones and a visual impact assessment (VIA) methodology [13]. This VIA methodology was called a visual contrast rating system, which evaluated the degree of contrast of the introduced project to existing landforms, vegetation and land use via shifts in line, form color and texture. Training sessions were held throughout the BLM districts including the first computer graphics session in 1978. The official VMS was published in 1980 as a two-volume set-one on the VMS itself [14] and one on simulation methods [15]. The author worked on a multidisciplinary team with Nick Feimer and Stephen Sheppard [16] at the University of California, Berkeley from 1977 to 1979 to test the reliability, validity and generalizability of the contrast rating methodology. One of the major findings from this study is that multiple raters (professional or trained) are needed to ensure reliability in use of such systems as well as detailed guidance for use of such systems to increase both reliability and validity [17] \& [18]. There have been few studies since [19]-[21] which have looked at validity and reliability issues of doing VIA work.

The Soil Conservation Service (SCS), which is now the Natural Resource Conservation Service (NRCS), developed their own landscape assessment method in 1972 with the hiring of Sally Schauman-their first landscape architect [2] \& [7]. SCS/NRCS, unlike the Forest Service or BLM, does not manage federal lands, but offers technical support 
programs and funding to private landowners to encourage better environmental practices. They also need to do environmental assessments for such federally funded projects as well. Under Sally Schauman's direction in 1978-SCS/NRCS published the inhouse document TR-65 [22], which provides guidance for assessment of landscape attributes, impacted by proposed projects. Subsequent technical manuals have been produced through SCS/NRCS service centers since that time.

The Federal Highway Administration (FHWA) within the US Department of Transportation provides financial support and technical assistance for highway construction and maintenance throughout the US. These projects can have major environmental impacts upon the landscape. Based upon the work of Jones and Jones-landscape architects out of Seattle Washington [23] \& [24] — the FHWA published their visual resource guidance document for highway projects in 1988 [25]. This document offers basic landscape and highway project visual inventory guidance as well as a visual impact methodology which can be used to compare transportation alternatives based on the attributes of landscape unity, vividness and integrity. The National Research Council-Transportation Board convened a panel in 2008 to reconsider the 1988 guidance for highway project visual impact assessment, and so hired a consultant group to undertake a study of VIA methods used by US State transportation agencies. See Palmer et al. [26], which summarizes part of this project as in regard to VIA practice across the US.

The US National Park Service (NPS) really has had no national guidance for visual or landscape management until recently. This is partially understandable as the NPS has, in many cases, separate legislation individually creating many of the national parks. One of the few comprehensive studies of landscape management alternatives was done for the Blue Ridge National Parkway in Virginia and Tennessee [27]. The author and James Palmer were involved in creating a landscape classification of the entire parkway corridor; developed color photographic simulations of different management alternatives (controlled burn vs. mechanical cutting of vegetation) and developed survey to test parkway user reactions to the simulated management alternatives. The NPS is in the process of developing multi-jurisdictional policy guidance for evaluating visual impacts of projects that may impact the scenic integrity of national parks. The NPS with US Environmental Protection Agency (USEPA) has sponsored extensive research on visibility degradation in the National Parks due to air pollution from 1979 [28] to the current time [29].

In 1988 the US Army Corps of Engineers (USACOE) published a report entitled Visual Resources Assessment Procedure (VRAP) for the US Army Corps of Engineers [30] \& [31]. This was based upon the methodology development and training work by the author and James Palmer from1983 until 1988. It was also in response to a National Academy of Science panel that was convened to address why aesthetic and other environmental values were not properly being addressed by the USACOE as part of environmental assessment for water resource projects. This guidance was embraced as we developed better procedures to ensure reliability and validity as part of the VRAP methodology. As a result the VRAP methodology is fairly time consuming and costly, 
which explains why it has not been heavily utilized by the USACOE, but is has been used by other federal and state agencies for power plants and water related development.

A major conference, which coalesced much of the Federal agency activity was held at Incline Village, Lake Tahoe Nevada in 1979. This meeting was attended by over 800 people from 48 states and 11 countries with over 104 presentations and papers over three days [4]. It was co-sponsored by the US Forest Service, BLM, SCS/NRCS, FHWA and US Geological Survey and reflected the state-of-the art of visual landscape resource management and assessment at that time. Some of the best contributions from that conference were complied into the book Foundations for Visual Project Analysis [32] that becomes the first professional reference book for the field in North America.

\section{Current VIA Challenges}

After the 1980's there has been little new work in visual resources assessment methodology aside from developing visual simulation digital technology. This new technology and software is useful for improving visibility assessment, 3-D modeling and producing more realistic visual simulation of landscape change. Such examples can be seen in the book by Bishop and Lange [33] on Visualization in Landscape and Environmental Planning and a special issue of Landscape and Urban Planning [34]. There was also not much visual perception research as summarized in 1982 by Zube sell and Taylor's [35] landmark paper.

On the other side of the pond in Europe and particularly the United Kingdom (UK) - there have been developments in the standardization of the visual impact assessment process, which is summarized in the book Guidelines for Landscape and Visual Impact Assessment [36] produced by the Landscape Institute and the Institute of Environmental Management and Assessment. This book includes specific chapters on:

- Description of the proposed project;

- Baseline studies;

- Identification and assessment of landscape and visual effects;

- Presentation techniques \& good practice;

- Consultation and review.

This basic VIA procedural guide has been utilized for large projects throughout the UK-particularly large wind farm projects. This brings us to the most recent issue affecting visual landscape assessment-renewable energy development. In the last 5 to 10 years we have seen a resurgence of VIA-particularly for large-scale wind turbine farms both on land and off shore. Some of these projects such as the proposed Cape Wind project between Cape Cod and Martha's Vineyard have proven to be very controversial [37] partially on aesthetic issues. These alternative energy development projects have caused the development of new VIA methods specifically for offshore wind farms in the UK [38]-[40], Australia [41] \& [42] and in the US [43]-[47].

So in summary the early surge of visual impact assessment and visual resource management systems was spurred by NEPA in the late 1970's through the 1980's followed 
by stagnation in VIA/VRM method development. We had a steady development of digital visualization tools through the 1990's to the current time followed by recent VIA interest due to new renewable energy development including wind and solar energy farms, and large-scale biomass energy development.

Given the recent surge in renewable energy development-there has been a "slight surge" of VIA methodology development sponsored mainly by the US Bureau of Land Management and the National Park Service. Such work was highlighted in the $2012 \mathrm{Na-}$ tional Association of Environmental Professionals (NAEP) meeting in Portland Oregon and includes:

- Visibility assessment of renewable energy projects [43]-[47];

- $\quad$ Air quality visibility impacts near and within national parks [29];

- Limited visual perception research in the US [20] [21] \& [48] Germany [49] and Australia [42]; and

- New mitigation measure effectiveness [50].

The other notable research-to-practice development is the US Forest Services work on Appendix J [51] of the Scenery Management System. This is a deliberate attempt to clarify, refine and extend an ecological approach to scenery management. One of the key objectives of Appendix $\mathrm{J}$ is to provide a method for sustaining valued scenery within an ecosystem management context. The specific methodology includes:

- Using indicators to identify and measure ecological sustainability; and

- Using criteria for assessing six levels of visual disturbance, which indicates scenic integrity [52].

Although such method development toward a more ecological approach is in many ways desirable-it also presents a dilemma. The dilemma is whether to compare future visual/scenic landscape change against present conditions or a projected future incorporating ecological as well as human changes in landscape conditions. Clearly the later is preferred but we need a sound basis for making such projections. Then we can add in the future impact so climate change affecting ecological landscape conditions. Stephen Sheppard's new 2012 [53] book Visualizing Climate Change may give us some guidance in this regard.

\section{Conclusion}

The basic issue for this author is that the visualization technology has outstripped sound VIA methodology development. Such methodology needs to meet basic standards of validity, reliability and generalizability [16] [20] \& [21]. This author has been an expert witness in court proceedings and quasi-judicial hearings over 35 years critiquing VIA methods used by consultants [54]. In many cases the basic step-by-step logic falls apart. Thus there is a need for best practice standards as well as sound VIA method development. Recently there has been progress both in the UK [38]-[40] and the US [44] \& [55] with development of VIA methodology specifically for the assessment of large-scale wind, solar and geothermal energy development as well as mitigation measures [56] but there is much methodology research work to be done. 


\section{References}

[1] Smardon, R.C. (1982) An Organizational Analysis of Federal Agency Visual Resource Management Systems. Unpublished Ph.D. Dissertation, Environmental Planning Program at the College of Environmental Design, University of California, Berkeley, 330 p. Available from International Microfilms, Ann Arbor.

[2] Smardon, R.C. (1986) Historical Evolution of Visual Resource Management within Three Federal Agencies. Journal of Environmental Management, 22, 301-317.

[3] 42 USC s. 4321 et seq. The National Environmental Policy Act of 1969.

[4] Elsner, G.H. and Smardon, R.C. (Tech. Coord.) (1979) Proceedings of Our National Landscape: A Conference on Applied Techniques for Analysis and Management of the Visual Resource, Incline Village, Nevada, 23-25 April 1979, USDA For. Serv. Gen. Tech. Rpt. PSW-35, Berkeley CA, Pacific SW For. \& Range Exp. Stn, 752 p. http://www.esf.edu/via http://www.treesearch.fs.fed.us/pubs/27530

[5] Bacon, W. (1979) The Visual Management System of the Forest Service, USDA. In: Elsner, G. and Smardon, R., (Tech. Coord.), Our National Landscape, 660. http://www.esf.edu/via http://www.treesearch.fs.fed.us/pubs/27530

[6] Ross Jr., R.W. (1979) The Bureau of Land Management and Visual Resource Management-An Overview. In: Elsner, G. and Smardon, R., (Tech. Coord.), Our National Landscape, 666-671. http://www.esf.edu/via http://www.treesearch.fs.fed.us/pubs/27530

[7] Schauman, S. and Adams, C. (1979) Soil Conservation Service Landscape Management. In: Elsner, G. and Smardon, R., (Tech. Coord.), Our National Landscape, 671-675. http://www.esf.edu/via http://www.treesearch.fs.fed.us/pubs/27530

[8] USDA, Forest Service (1973) National Forest Service Mgmt. Vol. 1, USDA Handbook 434, US Gov Print Off, Wash DC.

[9] USDA, Forest Service (1974) National Forest Landscape Mgmt. Vol. 2, Chap. 1. USDA Handbook 462, US Gov Print Off, Wash DC.

[10] Litton Jr., R.B. (1973) Landscape Control Points; a Procedure for Predicting and Monitoring Visual Impact. USDA, For. Serv. Res. Paper PSW-91, Berkeley, CA Pac. SW For. \& Range Exp. Stn.

[11] USDA, Forest Service (1976) Forest Service Manual Sections 2360.01-2363.37 and 2350, US Gov Print Off, Wash DC.

[12] USDA, Forest Service (1995) Landscape Aesthetics; a Handbook for Scenery Management. Agricultural Handbook No. 701. US Gov Print Off, Wash DC. http://www.esf.edu/via http://www.fs.usda.gov/Internet/FSE_DOCUMENTS/fsm9_005639.pdf

[13] USDI, BLM (1980) BLM Manual Sections 6300, 6310 and 6320, Visual Resource Mgmt. USDI, Bureau of Land Management, Wash DC. http://www.esf.edu/via

[14] USDI, BLM (1980) Visual Resource Management, US Gov Print Off, Wash DC.

[15] USDI, BLM (1980) Visual Simulation Techniques, US Gov Print Off, Wash DC.

[16] Smardon, R.C., Feimer, N.R., Craik, K.H. and Sheppard, S.R.J. (1983) Assessing the Reliability, Validity and Generalizability of Observer Based Visual Impact Assessment Methods for the Western US. In: Rose, R.D. and Chestnut, L.G., Eds., Managing Air Quality and Scenic Resources at National Parks and Wilderness Areas, Westview Press, Boulder, 84-102.

[17] Feimer, N.R., Craik, K.H., Smardon, R.C. and Sheppard, S.R.J. (1979) Appraising the Validity of Visual Impact Assessment Methods. Proceedings of Our National Landscape, Incline 
Village, 23-25 April 1979, 286-295. http://www.esf.edu/via

http://www.treesearch.fs.fed.us/pubs/27530

[18] Feimer, N.R., Smardon, R.C. and Craik, K.H. (1981) Evaluating the Effectiveness of Observer Based Visual Resource and Impact Assessment Methods. Landscape Research, 6, 112-116. http://dx.doi.org/10.1080/01426398108705963

[19] Miller, P.A. (1984) A Comparative Study of the BLM Scenic Quality Rating Procedure and Landscape Preference Dimensions. Landscape Journal, 3, 123-135.

[20] Palmer, J.F. (2000) Reliability on Rating Visible Landscape Qualities. Landscape Journal, 19, 166-178.

[21] Palmer, J.F. and Hoffman, R.E. (2001) Rating Reliability and Representation Validity in Scenic Landscape Assessments. Landscape and Urban Planning, 54, 149-161. http://dx.doi.org/10.1016/S0169-2046(01)00133-5

[22] USDA Soil Conservation Service (1978) Procedures to Establish Priorities in Landscape Architecture. USDA SCS Technical Release No. 65, US Government Printing Office, Washington DC.

[23] Blair, G.E., Isaacson, L. and Jones, G.R. (1979) A Comprehensive Approach to Visual Resource Management for Highway Agencies. In: Elsner, G. and Smardon, R., Eds., Proceedings of Our National Landscape, Incline Village, 23-25 April 1979, 660.

http://www.esf.edu/via http://www.treesearch.fs.fed.us/pubs/27530

[24] Jones G., Sorey, D. and Scott, C. (2012) Visual Resource Assessment for Regional Landscapes: A Modern Response to NEPA. 37 th Annual NAEP Conference on Science, Politics and Policy: Environmental Nexus, National Association of Environmental Professionals, Portland Oregon, 21-24 May 2012, 641-656.

[25] USDOT and FHWA (1988) Visual Impact Assessment for Highway Projects. Publication No. FHWA-HI-88-054, USDOT, Federal Highway Administration, Washington DC. http://contextsensitivesolutions.org/content/reading/visual-impact-2/

[26] Palmer, J.F., Churchward, C., Nassauer, J.I. and Swanwick, C.A. (2012) An Evaluation of the Visual Impact Assessment Process as Used by State Departments of Transportation in the USA. 37 th Annual NAEP Conference on Science, Politics and Policy. Environmental Nexus, National Association of Environmental Professionals, Portland Oregon, 21-24 May 2012, 735-750.

[27] Noe, F.P. and Hammitt, W.E. (1988) Visual Preferences of Travelers along the Blue Ridge Parkway. Scientific Monograph Series Number 18, USDI, National Park Service Monograph Series No. 18, USDI, National Park Service, Washington DC.

[28] US EPA (1979) Protecting Visibility: An EPA Report to Congress. US Environmental Protection Agency, Office of Air Noise and Radiation, Office of Air Quality Planning and Standards; Research Triangle Park, North Carolina, EPA-450/5-79-008.

[29] Molenar, J.V., Paterson, R.W. and Goodstein, M.D. (2102) Seeking Clarity: Scenic, Economic and Legal Views on Visibility. 37 th Annual NAEP Conference on Science, Politics and Policy: Environmental Nexus, National Association of Environmental Professionals, Portland Oregon, 21-24 May 2012, 767-817.

[30] Henderson, J.E., Smardon, R.C. and Palmer, J.F. (1988) US Army Corps of Engineers Visual Resources Assessment Procedure. Transportation Research Record, 67-71.

[31] Smardon, R.C., Palmer, J.F., Knopf, J., Grinde, K., Henderson, J.E. and Peyman-Dave, L.D. (1988) Visual Resource Assessment Procedure for US Army Corps of Engineers, Instruction Report EL-88-1, USACOE Waterways Experiment Station, Vicksburg, Miss. 
http://www.esf.edu/via

[32] Smardon, R.C., Palmer, J.F. and Felleman, J.F. (1986) Foundations for Visual Project Analysis. John Wiley and Sons, New York. http://www.esf.edu/via

[33] Bishop, I.D. and Lange, E. (Eds.) (2005) Visualization in Landscape and Environmental Planning. Taylor and Francis, London.

[34] Lange, E. and Bishop, I. (Eds.) (2001) Our Visual Landscape; Analysis, Modeling, Visualization and Protection. Landscape and Urban Planning, 54, 1-3. http://dx.doi.org/10.1016/S0169-2046(01)00121-9

[35] Zube, E.H., Sell, J.L. and Taylor, L.G. (1982) Landscape Perception: Research, Application and Theory. Landscape and Urban Planning, 9, 1-33. http://dx.doi.org/10.1016/0304-3924(82)90009-0

[36] Landscape Institute/Institute of Environmental Management and Assessment (LI/IEMA) (2002) Guidelines for Landscape and Visual Impact Assessment. SPON Press, London.

[37] Williams, W. and Whitcomb, R. (2007) Cape Wind: Money, Celebrity, Class Politics and the Battle for Our Energy Future. Public Affairs Book, New York.

[38] DTI (2005) Guidance on the Assessment of the Impact of Offshore Wind Farms: Seascape and Visual Impact. Report of the Department of Trade and Industry Publication 806666 UK.

http://www.decc.gov.uk/assets/decc/what $\% 20$ we\%20do/uk\%20energy\%20supply/energy\%2 0mix/renewable\%20\%energy/policy/offshore/rag/complete/file22852.pdf

[39] Hill, M., Briggs, J., Minto, P., Bagnall, D., Foley, K. and Williams, A. (2001) Guide to Best Practice in Seascape Assessment, Countryside Commission of Wales. Brady Simpson Marsh and University College Dublin.

http://www.marine.ie/NR/rdonlyres/683C8CDo-3367-47048542D3091607C9C2/0/interreg5 1.pdf

[40] Honor-McLennon and Envision (2006) Visual Representation of Wind farms: Good Practice Guidance. Report for the Scottish National Heritage, the South Scottish Forum and the Scottish Society for Direction and Planning. http://www.snh.gov.uk/docs/A305436.pdf

[41] Bishop, I.D. (2002) Determination of Thresholds of Visual Impact: The Case of Wind Turbines. Environment and Planning B: Planning and Design, 29, 707-718. http://dx.doi.org/10.1068/b12854

[42] Bishop, I.D. and Miller, D.R. (2007) Visual Assessment of Offshore Wind Turbines: The Influence of Distance, Contrast, Movement and Social Variables. Renewable Energy, 32, 814831. http://dx.doi.org/10.1016/j.renene.2006.03.009

[43] Palmer, J.F. (2012) Maine's Experience Evaluating When Scenic Impacts from Wind Energy Development Are Reasonably Adverse. 37 th Annual NAEP Conference on Science, Politics and Policy. Environmental Nexus, National Association of Environmental Professionals, Portland Oregon, 21-24 May 2012, 602-620

[44] Rooney, S., Dascomb, P., Korjeff, S. and Smardon, R. (2012) Technical Bulletin 12-001, Visual Impact Assessment Methodology for Offshore Wind Energy Conversion Facilities. Cape Cod Commission, Barnstable. http://www.esf.edu/via

[45] Sullivan, R.G., Kirchler, L.B., Cothren, J. and Winters, S.L. (2012) Preliminary Assessment of Offshore Wind Turbine Visibility and Visual Impact Threshold Distances. 37 th Annual NAEP Conference on Science, Politics and Policy. Environmental Nexus, National Association of Environmental Professionals, Portland Oregon, 21-24 May 2012, 943-969.

[46] Sullivan, R.G., Cothren, J., Williamson, M., Smith, P., McCarthy, J. and Kirchler, L.B. (2102) Visual Impact Risk Assessment and Mitigation Mapping System for Utility-Scale 
Wind Energy Facilities. 37 th Annual NAEP Conference on Science, Politics and Policy: Environmental Nexus, National Association of Environmental Professionals, Portland Oregon, 21-24 May 2012, 667-692.

[47] Sullivan, R.G., Kirchler, L.B., Lahti, T., Roche, S., Beckman, K., Cantwell, B. and Richmond, P. (2012) Wind Turbine Visibility and Visual Impact Distances in Western Landscapes. 37 th Annual NAEP Conference on Science, Politics and Policy: Environmental Nexus, National Association of Environmental Professionals, Portland Oregon, 21-24 May 2012, 897942.

[48] Ribe, R. (2012) How Do People's Demographic Attributes and Environmental Attitudes Relate to Their Perception of Scenic Beauty? The Case of Forests in the Pacific Northwest. 37 th Annual NAEP Conference on Science, Politics and Policy. Environmental Nexus, National Association of Environmental Professionals, Portland Oregon, 21-24 May 2012, 9711025.

[49] Roth, M. (2012) Visual Landscape Quality Assessment in Landscape Planning in Germany: A Validation Approach. 37 th Annual NAEP Conference on Science, Politics and Policy. Environmental Nexus, National Association of Environmental Professionals, Portland Oregon, 21-24 May 2012, 632-640.

[50] Schwarzler, K. and Cramer, G. (2012) The Art and Science of Camouflage for Visual Mitigation in the Landscape. 37 th Annual NAEP Conference on Science, Politics and Policy. Environmental Nexus, National Association of Environmental Professionals, Portland Oregon, 21-24 May 2012, 693-715.

[51] USDA Forest Service (Undated) Briefing Paper, Scenery Management System-Appendix J. US Forest Service, Washington DC.

[52] Spencer, J., Mosier, J. and Laughlin, N. (2008) SMS Appendix J Project Level Scenery Analysis Template. US Forest Service.

[53] Sheppard, S.R.J. (2012) Visualizing Climate Change: A Guide to Visual Communication of Climate Change and Developing Local Solutions. Rutledge Press, London.

[54] Smardon, R.C. and Karp, J. (1992) The Legal Landscape, Guidelines for Regulating Aesthetic and Environmental Quality. Van Nostrand Rhinehold, New York. http://www.esf.edu/via

[55] Sullivan, R.G. and Meyer, M. (2014) Guide to Evaluating Visual Impact Assessments for Renewable Energy Projects. Natural Resource Report NPS/ARD/NRR-2014/836 US National Park Service and Argonne National Laboratory.

[56] USDI Bureau of Land Management (2013) Best Management Practices for Reducing Visual Impacts of Renewable Energy Facilities on BLM-Administered Lands. USDI BLM, Wyoming Office, Cheyenne. 
Submit or recommend next manuscript to SCIRP and we will provide best service for you:

Accepting pre-submission inquiries through Email, Facebook, LinkedIn, Twitter, etc. A wide selection of journals (inclusive of 9 subjects, more than 200 journals)

Providing 24-hour high-quality service

User-friendly online submission system

Fair and swift peer-review system

Efficient typesetting and proofreading procedure

Display of the result of downloads and visits, as well as the number of cited articles

Maximum dissemination of your research work

Submit your manuscript at: http://papersubmission.scirp.org/

Or contact jep@scirp.org 